\title{
A Test of the validity of Crowding-out (or- in) hypothesis: A new examination of link between public borrowing and private investment in Emerging Europe
}

\author{
Mehmed Ganic $^{1 *}$, Lejla Hodzic ${ }^{2}$ and Ognjen Ridjic ${ }^{3}$ \\ ${ }^{1}$ Faculty of Business and Administration, International University of Sarajevo, Bosnia and \\ Herzegovina \\ E-mail: 〈mganic@ius.edu.ba \\ ${ }^{2}$ Faculty of Business and Administration, International University of Sarajevo, Bosnia and \\ Herzegovina \\ E-mail: 〈lejlahodzic1101@gmail.com〉 \\ ${ }^{3}$ Faculty of Business and Administration, International University of Sarajevo, Bosnia and \\ Herzegovina \\ E-mail: 〈oridic@ius.edu.ba〉
}

\begin{abstract}
This study seeks to test the existence of the crowding-out (or- in) hypothesis in a sample of 17 Emerging Europe countries divided in two panels. The study employs a panel autoregressive distributed lag (ARDL) model based on three estimators, Mean Group Estimator (MG), Pooled Mean Group (PMG) and Dynamic Fixed Effect (DFE), in order to evaluate the of stability of short run and long run coefficients using consistently compiled public borrowing and private investment data between 2000 and 2019. The empirical findings of the paper generally confirm the existence of a crowding out effect in both long run and short run in European post-transition countries, and in the long run for European transition countries. More specifically, elasticity of private investment with respect to public debt is greater in the European transition countries than in the European post-transition countries. However, the findings on the crowding out (in) effect of government spending and economic growth on private investment are mixed and conflicting in both the long run and the short run. Accordingly, the study recommends that selected countries should reassess their austerity agendas employed for lowering debt levels, and follow new strategies for managing public debt burden.
\end{abstract}

Keywords: Crowding (-in) out hypothesis, public debt, private investment, European transition and post-transition countries

Received: March 26, 2021; accepted: May 31, 2021; available online: June 29, 2021

DOI: $10.17535 /$ crorr.2021.0008

\section{Introduction}

The rapid increase in public sector debt is a phenomenon that has received considerable attention in both theoretical and empirical research, as well as among economic policy makers in recent decades. The great global imbalances that preceded the outbreak of the latest global financial crisis (2008-09) contributed to a rapid increase in government borrowing. In the literature, the term "crowding out effect" is very well-known where it refers to how rising public borrowing crowds out private demand. However, there is some ambiguity about the crowding out effect because there exists growing evidence about the crowding-in effect in different countries.

${ }^{*}$ Corresponding author. 
Although the importance of link between private investment and public investment has been widely examined, most of those studies, quite disappointingly, have been done for the region as a whole. Specifically, our research provides a valuable contribution to this area, especially in regard to European post-transition countries. Most empirical investigations have tested the crowding out (or-in) hypothesis for highly indebted and poor countries. There has been much less research on modestly indebted transition countries. In addition, many of these European transition countries have undergone significant on-going political and structural changes. Due to this fact, the rise of public debt might be a present burden in near future for these countries. This study aims to explore the link between private investment and public borrowing in emerging Europe by examining the validity of the crowding out (or-in) hypothesis. More specifically, this study focuses on common long run and short run coefficients in eight selected European transition countries (Albania, Belarus, Bosnia and Herzegovina, Georgia Serbia, Montenegro, North Macedonia and Moldova) and nine European post-transition countries (Bulgaria, Croatia, Czechia, Hungary, Latvia, Lithuania, Poland, Romania, and Slovakia). Consequently, the study seeks to ascertain whether an increase in public debt leads to a decrease (increase) in private investment, both in the long run and the short run. The PMG is used to test the stability of short run and long run variables employing consistently compiled public borrowing and private investment data.

The countries included in our study share similar cultural/historical legacies and socioeconomic characteristics. In some countries, the process of joining to the EU has already been completed (the European post-transition countries) while in others it is still in progress (the European transition countries). The literature on this issue remains scarce for the both groups of countries due to the recent establishment of government and public debt management policies, as well as recent public sector management reforms. However, taking into consideration that major structural changes in public debt management policies for the region have been happening for at least twenty years now (and that public investment are not more and less complementary to private investment but rather operate at different levels of efficiency) it seems appropriate to address this issue now. In fact, this study employs a panel ARDL model based on three estimators (MG, PMG and DFE) which provide certain advantages over the other types of dynamic panel models. In particular, there remains a lack of recent empirical studies, in both the short run and long run that have explored the crowding out (or-in) effect. The studies that do exist simply do not offer convincing arguments to explain the negative and positive relationships between public borrowings on private investment.

\section{Literature review}

The crowding-out (or-in) effect and its different forms have been studied for more than four decades now and remains a point of interest for many researchers. As a result, there is a substantial body of literature on this topic derived from theories of monetary and fiscal policy.

There is a clear short run correlation between public debt and interest rates [2]. Generally, increases in public debt lead to higher interest rates. Modigliani and Ando [30] attempted to evaluate the crowding-out effect more closely. They suggest that crowding out is only one of many effects that occurs in the process of public expenditure growth via bond issuance. This resulted in the creation of the crowding-out hypothesis as we more and less know it today. For example, Borensztein [10] was one of the first researchers who attempted to test the relationship between public debt and private investments. His study concluded that public debt burden acts as a disincentive for private investment.

A number of crowding out (or in) studies exist for individual countries (i.e. [6, 7, 16, 24]; etc.). The majority of these studies employed Vector Error Correction Modeling (VEMC) and Error Correction Modeling (ECM) to explore the links between public borrowing and private investments. However, this study focuses on the validity of the crowd-out (crowd-in) hypothesis 
in a cross-section of heterogeneous countries. Revealingly, recent empirical studies have shown mixed findings at a global level when testing the "crowding out" (or-in) effect hypothesis. For instance, one of those studies focused on channels of interest rate and models of crowding out [16]. They showed that government spending puts upward pressure on interest rates which in turn leads to lower levels of private investment. Thus, the debate about the "crowding out" (or-in) effect is not conclusive, and in fact, has initiated new controversies related to the short run and long run effects between public borrowings and private investment. The scope of the studies have varied significantly from one study to another in terms of the proxy variables included in the estimates of the influence that public borrowings have on private investment. Table 1 shows a brief summary of the current literature that is relevant to this research:

Deshpande's [14] research reveals the negative impact that public debt has on private investment while the time variable only has positive impact on investment until 1984. A similar study was conducted by [6] who identified the crowding out effect in eleven countries, while in eight countries he identified the crowding (in) effect. There was no statistical significance regarding the crowding out (or-in) effect in the other six countries of the study. In another study, authors [1] observed a crowding-in effect as it relates to public investment on private investment in eight countries, with a crowding out effect being found in nine countries, respectively. Emran and Farazi [17] investigated the causal effect of public borrowing and private investment by utilizing cross sectional data,. Their study indicated that private credit is reduced by $\$ 1.40$ if the government increases its borrowing by $\$ 1.00$. Elmendorf and Mankiw [16] examined interest rate channels and models of crowding out. They found that government spending puts upward pressure on interest rates and leads lower private investment. Broner, et.al. [11] found evidence of the crowding-out hypothesis in Euro zone countries, taking into consideration all the events surrounding the financial crisis from 2007. In their examination of the crowding out hypothesis, the authors concluded that the demand for public borrowing is higher among poorer Euro zone members. Erdem, et.al. [19] noted a negative correlation between public debt and government expenditures in the Euro zone between 2000 and 2015.

In addition, the crowding out hypothesis was also confirmed by the negative relationship between budget deficits and private investment. This indicates that budget deficit increases caused by large public debt burdens and debt servicing activities, leads to the crowding out of private investment. All of these relationships were confirmed for the short run period. In one of the most significant studies, [21] it is shown that lower levels of private investment are associated with higher levels of government debt.

On the other end of the debate, there are some researchers who found complementarity between public borrowing and private investment, thus supporting the hypothesis about the crowding-in effect rather than the crowding out effect. Aschauer [7] found that public investment crowds-in private investment. Similarly, two other studies also support the existence of the crowding-in effect public on private investment [3] and [5]. Authors [28] found a greater crowding-in effect in developing rather than developed countries by public investment.

In conclusion, it is clear that the existing empirical literature on this topic provides limited and conflicted evidence regarding a crowding out (or-in) effect that public borrowing has on private investment, particularly in European transition countries. European post-transition countries have been much less explored. Our study follows a different approach than the previous empirical studies listed in Table 1.

\section{Methodology}

Following some recent studies [11, 19], this study tests the existence the crowding-out (or- in) hypothesis in a sample of 17 emerging Europe countries divided in two panels. The study employs a cross country sample of eight selected European transition countries (Albania, Belarus, Bosnia and Herzegovina, Georgia, Moldova, Montenegro, North Macedonia, and Serbia,) and 
Table 1: Review of selected empirical studies

\begin{tabular}{|c|c|c|c|c|}
\hline Author(s) & Time span & Countries & Econometric method & Variables \\
\hline$[3]$ & $1979-1988$ & $\begin{array}{l}14 \text { OECD coun- } \\
\text { tries }\end{array}$ & $\begin{array}{l}\text { Panel Data Technique, } \\
\text { FE model, RE model }\end{array}$ & $\begin{array}{l}\text { government consumption, pub- } \\
\text { lic investment, private invest- } \\
\text { ment }\end{array}$ \\
\hline [14] & 1971- 1991 & $\begin{array}{l}13 \text { highly in- } \\
\text { debted countries } \\
\text { (HIPCs) }\end{array}$ & Panel Data Technique & $\begin{array}{l}\text { Import of capital goods, public } \\
\text { debt, private investment, public } \\
\text { sector investment }\end{array}$ \\
\hline$[6]$ & $1970-2000$ & $\begin{array}{l}25 \text { developing } \\
\text { countries }\end{array}$ & $\begin{array}{l}\text { Multivariater Probit } \\
\text { Model, Bivariate } \\
\text { Probit Model }\end{array}$ & $\begin{array}{l}\text { public (private) investment } \\
\text { to GDP, Government Size, } \\
\text { Economic Structure, Monetary } \\
\text { Conditions, Forex Regime, } \\
\text { Trade Openness, freedom of } \\
\text { Exchange in Financial Market }\end{array}$ \\
\hline$[1]$ & $1960-2014$ & $\begin{array}{l}17 \text { OECD coun- } \\
\text { tries }\end{array}$ & VAR estimation & $\begin{array}{l}\text { GDP, Gross fixed capital forma- } \\
\text { tion, direct taxes, inflation rate, } \\
\text { social contributions received }\end{array}$ \\
\hline$[17]$ & $1975-2006$ & $\begin{array}{l}60 \text { developing } \\
\text { countries }\end{array}$ & $\begin{array}{lrr}\text { OLS, } & \text { 2SLS, } & \text { Efficient } \\
\text { Two Step } & \text { GMM, } \\
\text { CUE-GMM } & \\
\end{array}$ & $\begin{array}{l}\text { private credit, borrowing by the } \\
\text { government, growth rate of per } \\
\text { capita income, inflation }\end{array}$ \\
\hline$[13]$ & 1970-2011 & $\begin{array}{l}12 \text { euro area } \\
\text { countries }\end{array}$ & $\begin{array}{l}\text { FE models, IVREG } \\
\text { models }\end{array}$ & $\begin{array}{l}\text { private saving/ investment rate, } \\
\text { gross government debt, fiscal in- } \\
\text { dicators, long-term (sovereign) } \\
\text { real interest rate, trade open- } \\
\text { ness }\end{array}$ \\
\hline$[28]$ & $2000-2009$ & $\begin{array}{l}23 \text { developed } \\
\text { countries and } \\
15 \quad \text { developing } \\
\text { countries }\end{array}$ & Panel Data Technique & $\begin{array}{l}\text { Government capital formation } \\
\text { expenditure, private invest- } \\
\text { ment, budget deficit, inflation } \\
\text { rate, GDP }\end{array}$ \\
\hline$[11]$ & $2000-2012$ & $\begin{array}{l}\text { Euro zone coun- } \\
\text { tries }\end{array}$ & Panel Data Technique & Public debt, private investment \\
\hline$[19]$ & $2000-2015$ & $\begin{array}{l}\text { Euro zone coun- } \\
\text { tries }\end{array}$ & Panel Data Technique & $\begin{array}{l}\text { Public debt, private investment, } \\
\text { government expenditure, real } \\
\text { interest rate, growth rate on pri- } \\
\text { vate investment }\end{array}$ \\
\hline$[5]$ & $1992-2015$ & $\begin{array}{l}4 \quad \text { countries in } \\
\text { East Africa }\end{array}$ & A panel ARDL model & $\begin{array}{l}\text { Public debt as } \% \text { of GDP, pri- } \\
\text { vate investment, Human cap- } \\
\text { ital development, GDP, infla- } \\
\text { tion, credit to private sector, } \\
\text { corruption control. }\end{array}$ \\
\hline$[21]$ & $1998-2014$ & 69 countries & Error correction model & $\begin{array}{ll}\text { investment-to-GDP } & \text { ratio, } \\
\text { investment-to-assets } & \text { ratio, } \\
\text { government debt over } & \text { GDP, } \\
\text { Investment, Cash Flow, and } \\
\text { Sales }\end{array}$ \\
\hline
\end{tabular}

Source: Compiled by the authors

nine European post transition countries (Bulgaria, Croatia, Czech, Hungary, Latvia, Lithuania, Poland, Romania, and Slovakia). The sample of countries included in this study was determined by the availability of data.

In the first stages of our econometric analysis, the stationarity of the series is checked with three different the panel unit roots as follows: Im-Pesaran-Shin (IPS, 2003) test [22], Levin, Lin and Chu (LLC, 2002) test [26] and Pesaran's (2007) CIPS test [36]. The LLC test [26] assumes that the structures of all panel units are homogeneous, whereby the null hypothesis assumes that all observation units contain a unit root $\left(H_{0}: \rho_{i}=0 \forall i\right)$ while the alternative hypothesis 
assumes that all panel units are stationary $\left(H_{1}: \rho_{i}=\rho<0 \forall i\right)$. In the IPS test [22], under the null hypothesis it is presumed that all series' are non-stationary, while under alternative hypothesis, a fraction of the series is stationary. This test for stationarity is convenient as it allows panel data to be unbalanced. In other words, the IPS test assumes cross-sectional independence where heterogeneity allows for serial correlation structure of the error term and for the form of sole deterministic effects [22].

The IPS test [22] allows heterogeneous autoregressive coefficients within the alternative hypothesis. It is presumed that under the null hypothesis all series are non-stationary $\left(H_{0}\right.$ : $\left.\rho_{i}=0 \forall i\right)$ against the alternative hypothesis of $H_{1}: \rho_{i}<0$ where $i=1,2,3 \ldots N_{1} ; \rho_{i}=0$, $i=N_{1}+1, N_{2}+2, \ldots N$. In other words, the IPS test [22] relaxes the assumption of homogeneity and assumes that the panel units do not converge to the equilibrium level at the same rate.

One of the reasons for selecting the Pesaran's (2007) CIPS test [36] was that it allows cross sectional dependence of the contemporaneous correlation where the null hypothesis assumes that all observation units contain a unit root while the alternative hypothesis assumes that all panel units are stationary.

In the second stages of econometric analysis, this study adopts the first generation heterogeneous panel cointegration test developed by Pedroni (Pedroni Residual Cointegration Test, [32]) and Kao Residual Cointegration Test [23] for panel data analysis to predict the presence of long-run relationships among variables. The application of the Pedroni (1999) test considers seven residual-based tests, divided into two types. The first types covers four panel test statistics, based on the within-dimension approach (the panel rho statistics, the panel v-statistics, the panel ADF statistics and the panel PP statistics). It assumes a common regression coefficient across all cross-sections or to be the same across all the cross sections.

The second type covers three group test statistics based on the between-dimension approach (the group rho statistics, the group PP statistics and the the group ADF statistics) which assumes that the regression coefficients vary across cross-sections and allows greater heterogeneity.

In both cases, the null hypothesis of no cointegration is tested against the alternative hypothesis of cointegration in heterogeneous panels. For instance, if the null hypothesis is rejected then the relevant variables are cointegrated for all cross-sections (within-dimension approach) and cointegration among the variables exists for at least one of the cross-sections (between-dimension approach). Furthermore, Pedroni [32] assumes that individual units are heterogeneous. In that case, a cointegration equation of the model can be seen from equation 1 :

$$
y_{i, t}=\alpha_{i}+\delta_{i} t+\beta_{1 i} x_{1 i t}+\beta_{2 i} x_{2 i t}+\ldots+\beta_{M i} x_{M i t}+e_{i t} i=1, \ldots, N, t=1, \ldots, T m=1, \ldots, M
$$

where $T$ refers to the number of observations over time, $\mathrm{N}$ denotes the number of individual countries in panel, and $M$ is the number of regression variables. The slope coefficients of $\beta_{1 i}, \beta_{2 i}, \ldots, \beta_{M i}$ in the model can vary across individual counties of the panel. In the equation 1 , parameter $\alpha_{i}$ denotes the member specific intercept, or fixed that also can vary across individual members. The model allows that parameter $\delta_{i}$ presents deterministic time trend specific for individual counties of panel.

In addition to Pedroni's cointegration test [32], the study employed Kao Residual Cointegration Test [23]. It refers to residuals from static regression with fixed effects, which include potentially co-integrated variables, retrieves residuals to test whether a unit root exists via the $\mathrm{ADF}$ test.

If there is no cointegration or if there are doubts about the validity of the estimates from the previous method(s), the ARDL estimators are recommended as suitable estimators for such panel settings. Accordingly, three estimators are utilized to assess the relationship between private investment and economic growth (MG, PMG and DFE) in order to explore the existence of stable short run and long run coefficients. 
If there is no-cointegration or there is doubt about the validity of the estimates from the previous method(s), the ARDL estimators are recommended as suitable estimators for such panel setting. Accordingly, three estimators are utilized to assess the relationship between private investment and economic growth (MG, PMG and DFE) to explore the existence of stability of short run and long run coefficients.

There are few assumptions when utilizing the PMG estimator that need to be made: a) between the dependent and explanatory variables a long run relationship exists; b) there is a fixed effect heterogenity in the long run specification, and c) the residual of the model should be serially uncorrelated so that explanatory variables are treated as exogenous [34]. The PMG estimator is seen as an intermediate estimator which allows for homogeinity in the long run coefficients, but imposes heterogeneity in the short run coefficients and the error variances. However, the MG estimator assumes heterogeinity of all coefficients, intercepts and slopes, and estimates different coefficients for each panel separately while unweighted averages of the individual coefficients are computed for the whole panel. The DFE estimator developed by [34] have some similarities with the PMG estimator. In fact, the DFE estimator restricts the speed of adjustment and equalizes the short term coefficients. In the long run, it imposes restrictions on the slope coefficient and requires error variance to be equal.

MG estimators [33] allows for the slopes and intercepts to be different across counties. In this technique, coefficients are calculated as unweighted means of the estimated coefficients for separate individual countries. Therefore, no restrictions are imposed; rather coefficients are allowed to be heterogeneous in both the long-run and short-run and are subsequently allowed to vary. The only prerequisites are related to the need to obtain large time-series datasets, and the need for cross-country dimensions to be sufficient. Moreover, average estimators (MG) for small $\mathrm{N}$ are prone to outliers and small model permutations. Initially, the MG model as developed by [33] can be written as:

$$
y_{i, t}=\beta_{i}+\beta^{\prime} x_{i t}+u_{i t} i=1, \ldots, N, t=1, \ldots, T
$$

where $y_{i t}$ denotes the vector of the dependent variable, $x_{i t}$ is the matrix of regressors and $u_{i t}$ is the vector of residuals.

It is further obtained by first using OLS to get the individual estimates of the slope parameters. The MG model can then be written with $\hat{\beta}_{M G}$ (the unweighted average of country specific estimates):

$$
\hat{\beta}_{M G}=N^{-1} \sum_{i=1}^{N} \hat{\beta}_{i}
$$

And, the variance of these estimators can be estimated as follows:

$$
\operatorname{var}\left(\hat{\beta}_{M G}\right)=\frac{1}{N(N-1)} \sum_{i=1}^{N}\left(\hat{\beta}_{i}-\bar{\beta}_{l}\right)^{2}
$$

Moreover, the PMG model developed by [35] takes the following form:

$$
y_{i t}=\sum_{j=1}^{p} \lambda_{i j} y_{i, t-1}+\sum_{j=0}^{q} \delta_{i j}^{\prime} x_{i, t-1}+\mu_{i}+u_{i t}
$$

Where $x_{i, t}$ denotes the $k \times 1$ vector of explanatory variables for group $i, \delta_{i j}^{\prime}$ denotes the $k \times 1$ vector of heterogeneous coefficients, and $\lambda_{i j}$ denotes the coefficients with the lagged dependent variable. $\mu_{i}$ is a label for fixed effects. To get the relationship between private investment and public debt the panel ARDL model employed here can be expressed as follows: 


$$
y_{i t}=\alpha_{i}+\sum_{l=1}^{p} \beta_{0} y_{i, t-l}+\sum_{l=1}^{q} \beta_{1} d_{i, t-l}+\sum_{l=0}^{q} \beta_{2} x_{i, t-l}+u_{i t}
$$

In the light of the previous model (Eq. 6), we follow a similar form of re-parameterization that was done by [4] which is specified as follows:

$\nabla y_{i t}=\alpha_{i}+\phi_{i}\left(y_{i, t-1}-\gamma_{1} d_{i, t-1}-\gamma_{2} x_{i, t-1}\right) \sum_{l=1}^{p} \lambda_{i l} \nabla y_{i, t-1}+\sum_{l=1}^{q-1}=\lambda_{i l}^{\prime} \nabla d_{i, t-l}+\sum_{l=0}^{q-1} \lambda_{i l}^{\prime \prime} \nabla x_{i, t-l}+u_{i t}$

Where the subscript $(i, t)$ refers to country (from 1 to 17 ) and time period between 2000 and 2019 , respectively, $y$ is the the main dependent variable GFXPrivate, $d$ is public debt, $x$ denotes two control variables: government spending and GDP growth rate. The short run coefficients of the lagged dependent variable $\left(\lambda, \lambda^{\prime}\right.$ and $\left.\lambda^{\prime \prime}\right)$ represent public debt, government spending and GDP growth rate while $y_{1}$ and $y_{2}$ are the long run coefficients public debt and other control variables. And finally, $\phi_{i}$ denotes speed of adjustment parameter. The main dependent variable GFXPrivate (Gross fixed capital formation, private sector as \% of GDP, World Bank's World Development Indicators, World bank database) is used as a proxy for private investment. It is included in the model because the same variable was utilized in order to explore the impact of the crowd out (in) effect in 17 OECD countries through VAR analysis [1] and one other the study that used of a panel of 116 developing countries between 1980 and 2006 [12]. This variable is taken to check for the possible existence of a potential displacement effect of Gross fixed capital formation caused by increases of public debt.

There have been previous empirical studies that have explored the relationship between private investment and public borrowing. Almost all of them used the same or similar variables in their models as we did in this analysis. Public debt was proxied by the general government consolidated gross debt as a \% of GDP (PDGDP, IMF World Economic Outlook) to measure its impact on private investment. It assumes that this variable is a good predictor changes in private investment. It also offers a theoretical background that suggests that increases in public debt put upward pressure on interest rates which then lead to declines in private investment $[4,14,21]$. However, the available evidence shows mixed results that causes ambiguity.

The control variables of government expenditure (GOVEXPEND) and annual GDP growth rate (RGROWTH) are included in the econometric model. The variable of government expenditure (GOVEXPEND, World Bank's World Development Indicators, World bank database) was represented through the sum of all expenditures as a percentage of GDP that the government of any country has made. This variable is included in our model because there is some theoretical beliefs about the crowding-in effect (The Keynesian theory) that public investment through government spending increases private investment through the multiplier effect. However, in some empirical studies, there is a dilemma about the relationship between government capital expenditure and private investment. For example, [12, 7, 9] and [19] supported the view that there is a negative impact on private investment while others [20], [20, 29] confirmed a positive impact on private investment.

RGROWTH (World Bank's World Development Indicators, World bank database) is included based on a litany of evidence $[4,27,15]$ that suggests a highly significant link between annual GDP growth rate and levels of private investment. For example, [15] suggest that economic growth causes capital accumulation.

Finally, in order to choose between efficiency and consistency of MG, PMG, and DFE estimators, this study employs the Hausman restriction test on coefficients based on the ARDL model. It aims to check and make comparison between the significant differences between PMG, MG, and DFE estimators. It then aims to select the best of them. If empirical findings indicate 
the existence of homogeneity in the long-term relationship, the application of the PMG method provides efficient and consistent estimates over the two rest estimators. If the null hypothesis about the homogeneity of regression parameters in the long run is rejected, the PMG estimate becomes inconsistent. So, the MG or the DFE method is applied, which provides consistent estimates under these conditions.

\section{Results and Discussion}

Three different sets of first and second generation panel unit roots are utilized to test variable stationarity. They are: Im-Pesaran-Shin (2003) test [22], Levin, Lin and Chu (2002) test [26] and Pesaran's (2007) CIPS test [36]. Two tests of the first generation (IPS and LLC tests) assume cross sectional independence while the CIPS test allows cross sectional dependence. The study was not able to reject the null hypothesis for the GFXPrivate, PDGDP and RGROWTH series for the constant and trend term when expressed in level form (IPS test) and GFXPrivate for constant in the case of Pesaran's (2007) CIPS test. However, the null hypothesis is rejected after first differencing. All three panel tests reject the null hypothesis of nonstaniority for the first differenced variables. This means that our panel variables are stationary and integrated of an order one (I) at the $1 \%$ significance level except for the variable PDGP (IPS test) which is significant at the $10 \%$ level (Table 2). The second generation Pesaran's (2007) CIPS test was examined by using the constant term and with the constant term and trend. The findings of Pesaran's (2007) CIPS test reveals that the variables are stationary and integrated of an order one (I). Moreover, it allows us to conduct the Pedroni test [32] and Kao Residual Cointegration Test [23] in order to examine whether or not there is a cointegration equation among the selected variables.

Table 2: Panel Unit Root Tests

\begin{tabular}{|c|c|c|c|c|c|c|}
\hline \multirow{2}{*}{} & \multicolumn{2}{|c|}{ IPS test } & \multicolumn{2}{c|}{ LLC test } & \multicolumn{2}{c|}{ CIPS test } \\
\cline { 2 - 7 } & Constant & $\begin{array}{c}\text { Constant } \\
\text { and trend }\end{array}$ & Constant & $\begin{array}{c}\text { Constant } \\
\text { and trend }\end{array}$ & Constant & $\begin{array}{c}\text { Constant } \\
\text { and trend }\end{array}$ \\
\cline { 2 - 7 } & \multicolumn{7}{|c|}{ At level } \\
\hline GFXPrivate & $-1.7897^{* *}$ & 0.0335 & $-3.1689^{* * *}$ & $-2.9355^{* * *}$ & -2.032 & $-2.637^{*}$ \\
\hline PDGDP & -1.2214 & -0.1547 & $-2.8103^{* * *}$ & $-2.5189^{* * *}$ & $-3.197^{* * *}$ & $-3.009^{* * *}$ \\
\hline RGROWTH & $-2.9523^{* * *}$ & -1.2742 & $-4.2271^{* * *}$ & $-3.4262^{* * *}$ & $-3.377^{* * *}$ & $-4.977^{* * *}$ \\
\hline GOVEXPEND & $-5.1665^{* * *}$ & $-3.3687^{* * *}$ & $-5.8560^{* * *}$ & $-4.8506^{* * *}$ & $-3.377^{* * *}$ & $-3.404^{* * *}$ \\
\hline & \multicolumn{7}{|c|}{ At first differences } & $-4.952^{* * *}$ & $-5.017^{* * *}$ \\
\hline GFXPrivate & $-7.0855^{* * *}$ & $-4.7667^{* * *}$ & $-7.9007^{* * *}$ & $-6.4821^{* * *}$ & $-4.960^{* * *}$ \\
\hline PDGDP & $-3.5449^{* * *}$ & $-1.3681^{*}$ & $-2.5059^{* * *}$ & $-1.6966^{* *}$ & $-3.980^{* * *}$ & $-4.260^{* *}$ \\
\hline RGROWTH & $-10.7546^{* * *}$ & $-7.8070^{* * *}$ & $-11.0528^{* * *}$ & $-8.4045^{* * *}$ & $-3.404^{* * *}$ & $-4.946^{* * *}$ \\
\hline GOVEXPEND & $-9.0166^{* * *}$ & $-6.1329^{* * *}$ & $-9.3959^{* * *}$ & $-7.1152^{* * *}$ & $-4.977^{* * *}$ & $-4.946^{* * *}$ \\
\hline
\end{tabular}

Source: Authors' calculations: Im, Pesaran and Shin W-stat, ADF-Fisher Chi square, the null hypothesis is presence of unit root, ${ }^{*}, * *, * *$ indicates significant at $10 \%, 5 \% .1 \%$ at level.

The long run relationship between the variables GFXPrivate and PDGDP was examined by employing two panel cointegration tests: a Pedroni test [31] and a Kao Residual Cointegration Test [23]. First, the null hypothesis of no cointegration against the alternative hypothesis of cointegration was tested by using Pedroni's test [32] through Group mean statistics that average the results of individual test statistics and Panel statistics that pools the statistics with the within dimension. It rejects the null of hypothesis of no cointegration between used variables in 
terms of Panel and Group ADF and PP statistics. In fact, the outcome of the Pedroni cointegration test indicates that two out of the four panel statistics and two of the three group statistics (with $\mathrm{ADF}-\mathrm{t}$ and $\mathrm{PP}-\mathrm{t}$ statistics) confirm the existence of panel cointegration (Table 3). In addition, the cointegration assumption between private investment and explanatory variables was tested by Kao, Spurious regression and residual-based tests for co-integration in panel data for estimating their long-run behavior.

Table 3: Panel cointegration tests

\begin{tabular}{|c|c|c|}
\hline & \multicolumn{2}{|c|}{ Tests } \\
\hline \multirow{2}{*}{ ADF Statistics } & \multicolumn{2}{|c|}{ Kao Residual Cointegration Test } \\
\cline { 2 - 3 } & \multicolumn{2}{|c|}{$-2.515263^{* * *}$} \\
\hline & Pedroni Residual Cointegration Tests \\
\cline { 2 - 3 } & Within Dimension & Between-Dimension \\
\hline ADF Statistics & $-6.456864^{* * *}$ & $-4.799587^{* * *}$ \\
\hline PP Statistics & $-7.403208^{* * *}$ & $-8.415791^{* * *}$ \\
\hline
\end{tabular}

Source: Authors' calculations ${ }^{* * *}$ indicates significant at $1 \%$ at level.

In accordance with the results obtained (Table 3), the Null hypothesis is strongly rejected for all explanatory variables in favor of the alternative hypothesis (panels in the data are co integrated).

Keeping in mind that cointegration is confirmed by both panel cointegration test results, the study continued to utilize the panel ARDL model in order to examine the long run and the short run relationship between private investment and public debt. Table 4 reports the estimation output of MG, PMG and DFE models where these models provide the short run and long run impacts of public debt on private investment. These three alternative dynamic panel data estimators are utilized to explore dynamic effects from a general ARDL model.

Moreover, the Hausman test is utilized in order to choose the most efficient and consistent estimator of MG, PMG and DFE. In the first panel (the European post transition countries) the findings of Hausman test chi2 $(2)=3.62$ and Prob $>$ chi2 $(2)=0.3060$ implies that the PMG estimator is more suitable than the MG estimator. Also, between the PMG and the DFE estimators, the Hausman test with score of $\operatorname{chi} 2(2)=0.331$ and Prob $>$ chi2 $=0.675$ indicates that the PMG is a more efficient estimator than the MG and the DFE. Similarly, it was confirmed in the second panel (the European transition countries) between the PMG and the MG estimators where the Hausman test had a score of chi2 $(2)=3.74$ and Prob $>$ chi2 $=0.2912$ as well as between the PMG and the DFE estimators with a score of $\operatorname{chi} 2(2)=2.04$; Prob $>$ chi2 $=0.5648$.

In both panels, the null hypothesis related to the non-existence of systematic differences between estimators (MG, PMG and DFE) is not rejected at the $1 \%$ level. This seems to imply that the long run estimates are more homogenous because the PMG estimator is most efficient and consistent.

The error correction term for the two subpanels (the European post-transition countries and the European transition countries) is significant with a value of negative 0.291, and 0.353, respectively in the PMG estimates. Accordingly, the null hypothesis of no long-run relationship is rejected.

These outputs imply that effects convergence to the long run equilibrium path occurs at speed of $29.1 \%$ (European post transition countries) and $35.3 \%$ (European transition countries) annually. In addition, it generally confirms that the error corrections terms fall into the dynamic stable range indicating that the long-run effects of public debt on private investment exist 
Table 4: The Panel ARDL estimation

\begin{tabular}{|c|c|c|c|c|c|c|}
\hline \multicolumn{4}{|c|}{ European post-transition countries } & \multicolumn{3}{|c|}{ European transition countries } \\
\hline \multicolumn{7}{|c|}{ Long Run Equation } \\
\hline & MG & PMG & DFE & MG & PMG & DFE \\
\hline \multirow{2}{*}{ PDGDP } & .0182609 & -.0254105 & .0130773 & -8.049085 & -.1061752 & -.03582 \\
\hline & {$[.08015]$} & {$[.00941]^{* * *}$} & {$[.05108]$} & {$[8.0891]$} & {$[.02278]^{* * *}$} & {$[.06087]$} \\
\hline \multirow{2}{*}{ RGROWTH } & 1.870269 & .1901563 & 1.513631 & -89.97583 & .4674058 & .8403062 \\
\hline & {$[.987030]^{* *}$} & {$[.08619]^{* *}$} & {$[.38755]^{* * *}$} & {$[90.4109]$} & {$[.18479]^{* *}$} & {$[.36595]^{* *}$} \\
\hline \multirow{2}{*}{ GOVEXPEND } & -.0424091 & .1939209 & .2100794 & .3721736 & -.4039376 & -.3449487 \\
\hline & {$[.63126]^{*}$} & {$[.10078]^{* *}$} & {$[.29841]$} & {$[.429944]$} & {$[.150637]^{* * *}$} & {$[.22577]$} \\
\hline \multicolumn{7}{|c|}{ Short Run Equation } \\
\hline \multirow{2}{*}{ ECT } & -.483532 & -.291264 & -.227935 & -.460398 & -.353341 & -.2795455 \\
\hline & {$[.090952]^{* * *}$} & {$[.07441]^{* * *}$} & $.04699]^{* * *}$ & {$[.12061] * * *$} & {$[.08575]^{* * *}$} & {$[.055924] * * *$} \\
\hline \multirow{2}{*}{ D1. PDGDP } & .0497312 & -.1418093 & -.015654 & .1118333 & .0361011 & .0264485 \\
\hline & {$[.0528359]$} & {$[.047412] * * *$} & {$[.0385964]$} & [.1194039] & {$[.0495437]$} & {$[.017899]$} \\
\hline \multirow{2}{*}{$\begin{array}{l}\text { D1. } \\
\text { RGROWTH }\end{array}$} & -.1336105 & -.0064287 & -.0664832 & -.0556596 & -.006026 & -.0103366 \\
\hline & {$[.0555562]^{* *}$} & {$[.0230154]$} & {$[.0377973]^{*}$} & {$[.0628616]$} & {$[.0685786]$} & {$[.0661566]$} \\
\hline \multirow{2}{*}{$\begin{array}{l}\text { D1. GOVEX- } \\
\text { PEND }\end{array}$} & .0739298 & -.0502171 & .0304873 & -.2116513 & -.0757268 & -.0659848 \\
\hline & {$[.0995991]$} & {$[.0832334]$} & {$[.0609115]$} & {$[.1648824]$} & {$[.1314988]$} & {$[.0759267]$} \\
\hline \multirow{2}{*}{ cons } & 3.452725 & 3.229755 & 1.335761 & 7.387864 & 12.50888 & 8.444618 \\
\hline & [6.81961] & {$[.793672]^{* * *}$} & [2.81405] & [7.45455] & {$[2.6893]^{* * *}$} & $[3.49601]]^{* *}$ \\
\hline $\begin{array}{l}\text { Number of } \\
\text { observations }\end{array}$ & 171 & 171 & 171 & 140 & 140 & 140 \\
\hline $\begin{array}{l}\text { Hausman test } \\
\text { PMG vs, MG }\end{array}$ & \multicolumn{3}{|c|}{$\operatorname{chi} 2(2)=3.62 ;$ Prob $>$ chi $2=0.3060$} & \multicolumn{3}{|c|}{$\operatorname{chi} 2(2)=3.74 ;$ Prob $>\operatorname{chi} 2=0.2912$} \\
\hline $\begin{array}{l}\text { Hausman test } \\
\text { PMG vs, DFE }\end{array}$ & \multicolumn{3}{|c|}{$\operatorname{chi} 2(2)=0.331 ;$ Prob $>\operatorname{chi} 2=0.675$} & \multicolumn{3}{|c|}{$\operatorname{chi} 2(2)=2.04 ;$ Prob $>$ chi $2=0.5648$} \\
\hline
\end{tabular}

Source: Authors' calculations , *,**,*** indicates significant at 10\%, 5\%. $1 \%$ at level.

The standard error is shown in parentheses [ ]

for the MG, PMG, and DFE estimates. In the long term relationship, the findings of the PMG estimator indicate an inverse statistical significant link between public debt and private investment for both panels (crowd out effect) while we held RGROWTH and GOVEXPEND as control variables in the debt-investment model.

In the long run, it indicates that the variable of PDGP exerts a strong negative and statistically significant relationship on private investment at $1 \%$ for both panels. This relationship is in conformity with earlier studies done by $[11,14,19]$, and many others. Hence, this estimate implies that for European post transition countries 1\% change in public debt leads to a $0.025 \%$ decrease in private investment and a $0.10 \%$ decrease for the European transition countries (Table 5). It also implies that the elasticity of private investment with respect to public debt is greater in European transition countries than in European post-transition countries. Revealingly, a variable of RGROWTH exerts a statistically positive impact on private investment in both panels at the 5\% level (crowd in effect). Furthermore, according to the PMG estimates, the effect of government spending on private investment in European post-transition countries is significantly positive (crowd in effect), while in European transition countries it is significantly negative (crowd out effect).

As shown in Table 5, a 1\% increase in GOVEXPEND leads to increased private gross fixed capital formation by $0.19 \%$ for the European post-transition countries and a decrease of $0.4 \%$ for the European transition countries. This relationship in the long run for the European post-transition countries confirms the earlier findings of [29] and [20] while for the European transition countries it confirms the findings of $[12,7,9]$ and [19].

However, according to the results for European post-transition countries in the MG estima- 
tor, evidence shows that only control variables of RGROWTH (crowd in effect) and GOVEXPEND (crowd out effect) have a significant effect on private investment, while with the DFE estimator, only control the variable of RGROWTH (crowd in effect). In the case of European transition countries, the study did not find any significance in the relationship between selected variables and public debt in the MG model while there is a significant relationship between RGROWTH and private investment in DFE model at the 5\% level (crowd in effect).

In the short run, there are some mixed and unclear findings relating to both panels. The findings from Table 5 suggest that in the short run an increase in public debt moves inversely with GFXPrivate in the region (crowd out effect) only for the European post-transition countries at the $1 \%$ level in PMG estimates but not for European transition countries. In fact, the PMG estimates for a short run suggest that a $1 \%$ change in public debt leads to a $0.14 \%$ decrease in private investment European post-transition countries. This is in line with the findings of [3], and [11].

In fact, according to PMG estimates, there is no significant relationship between control variables and private investment (in the short run) while the variable RGROWTH is shown as statistically significant at the 5\% level in MG estimates and $10 \%$ level in DFE estimates for the European post-transition countries (crowd out effect).

Interestingly, the results for European transition countries in the short run reveals that there is not any significance relationship between variables. This implies that there are no instant responses of private investment to variations in any types of variables in all the estimators. The last one in the short run can be explained with some conclusions that, due to the increase in public debt stocks, the government needs to increase its spending for the purpose of debt servicing and debt repayments. While the variable total government expenditure was statistically significant in the long run for the European post-transition countries, it is negative and statistically insignificant in the short run.

Generally, while both groups of countries have relatively similar practices regarding how they link private investment and public debt, in the long run while they differ significantly in the short run. Therefore, the differences in findings might be attributable to the scope of countries included in this research. In fact, the findings of our study are inconsistent with the aforementioned investigation done by [15], and [19] in terms of correlation between growth rate and private investment in the short run. One explanation for this is that the level of GDP across the European transition and European post-transition countries is low and differ in account to panel heterogeneity.

\section{Conclusion}

The study examined the link between private investment and public debt using three ARDL estimators comparing European post-transition rather than the European transition countries. The Hausman test confirmed that PMG estimates are more efficient and consistent than MG and DFE in both panels.

The empirical evidence of the study generally confirms the existence of a crowding out effect in European post-transition countries in both the short run and the long run. More specifically, the elasticity of private investment with respect to public debt is greater in European transition countries than in European post-transition countries. In the short run, evidence on direct effect public debt on private investment is weak (European transition countries). In fact, there is little to no evidence that public debt crowds out private investment when we use RGROWTH and GOVEXPEND as control variables. In addition, there are some mixed and inconsistent findings in both long run and short run related time frames with the crowding effect of government spending on private investment. In European transition countries, government spending crowds out private investment (in the long run) and crowds in private investment (the European posttransition countries). Additionally, it appears that GDP growth exerts a crowding in effect 
in the long run in European post-transition countries while in the short run there are some mixed and inconsistent the findings. In addition, our findings suggest that there is a crowding in effect for the variable of government spending in the short run (the European post-transition countries- PMG estimator) but not for the European transition countries.

Accordingly, the study recommends that selected countries should reassess their austerity agendas employed for lowering debt levels and follow new strategies for managing their public debt burdens. In conclusion, further research should look into the effects of various components of government spending on private investments. Further research should also consider the uncertainty and political situation of each country in order to investigate the crowding out (or-in) effect of private investment.

\section{References}

[1] Afonso, A. and St Aubyn, M. (2019). Economic growth, public, and private investment returns in 17 OECD economies. Port Econ J (2019) 18:47-65. doi: 10.1007/s10258-018-0143-7.

[2] Ardagna, S. Caselli,F. and Lane, T. (2007). Fiscal Discipline and the Cost of Public Debt Service: Some Estimates for OECD Countries, Topics in Macroeconomics 7(1):1417-1417, doi: 10.2202/1935-1690.1417.

[3] Argimón, I. Gonzalez-Paramo, J.and Roldan, J.M. (1997). Evidence of Public Spending Crowding-Out from a Panel of OECD Countries, Applied Economics, 29(8):1001-10. doi: 10.1080/000368497326390.

[4] Asteriou, D., Pilbeam, K. and Pratiwi, C.E. (2021). Public debt and economic growth: panel data evidence for Asian countries. J Econ Finan 45, 270-287. doi: 10.1007/s12197-020-09515-7.

[5] Aswata, B.M., Nnyanzi, B.J. and Bbale, M.J. (2018). Debt, Corruption and Investment in East Africa: A Panel ARDL Analysis, Modern Economy 09(12):2012-2038. doi: $10.4236 /$ me.2018.912126.

[6] Atukeren, E. (2004). Interactions between public and private investment: Evidence from developing countries, Swiss Institute for Business Cycle Research (KOF). Zurich, Switzerland: Swiss Federal Institute of Technology-Zurich (ETH Zurich). doi: 10.1111/j.0023-5962.2005.00290.x.

[7] Aschauer, D. (1989). Does public capital crowd out private capital? Journal of Monetary Economics, 1989, vol. 24, issue 2, 171-188. doi: 10.1016/0304-3932(89)90002-0.

[8] Aschauer, D. (1985). Fiscal Policy and Aggregate Demand, American Economic Association, vol. 75, no. 1, pp. 117-127, 1985. https://www.jstor.org/stable/1812707.

[9] Blejer, I. and Khan, M. (1984). Government Policy and Private Investment in Developing Countries, Staff Papers (International Monetary Fund). Vol. 31, No. 2 (Jun., 1984), pp. 379-403. doi: $10.2307 / 3866797$.

[10] Borensztein, E. (1990). Debt overhang, credit rationing and investment, Journal of Development Economics, 1990, vol. 32, issue 2, 315-335. doi: 10.1016/0304-3878(90)90041-9.

[11] Broner, F., Erce, A., Martin, A. and Ventura, J. (2014). Sovereign debt markets in turbulent times: Creditor discrimination and crowding-out effects. Journal of Monetary Economics, 2014, vol. 61, issue C, 114-142. doi: 10.1016/j.jmoneco.2013.11.009.

[12] Cavallo, E. and Daude, C. (2011). Public investment in developing countries: A blessing or a curse?, Journal of Comparative Economics, vol. 39, pp. 65-81. doi: 10.1016/j.jce.2010.10.001.

[13] Checherita-Westphal, C., and P. Rother (2012). The impact of high government debt on economic growth and its channels: An empirical investigation for the euro area. European Economic Review, 56(7):1392- 1405. doi: 10.1016/j.euroecorev.2012.06.007.

[14] Deshpande, A., (1997). The debt Overhang and the Disincentive to Invest, Journal of Development Economics, 52, 169-187. doi: 10.1016/s0304-3878(96)00435-x.

[15] Easterly, W. and Levine, R. (2001). It's Not Factor Accumulation: Stylized Facts and Growth Models, The World Bank Economic Review Vol. 15, No. 2 (2001), pp. 177-219 doi: $10.2139 /$ ssrn.269108.

[16] Elmendorf, E. and Mankiw, G. (1999). Government Debt. In (J. B. Taylor \& M. Woodford (ed.)) Handbook of Macroeconomics 1, part 3: 1615-1669. https://econpapers.repec.org/bookchap/eeemacchp/1-25.htm. 
[17] Emran, M.S., Farazi, S. (2009), Lazy Banks? Government Borrowing and Private Credit in Developing Countries. Institute for International Economic Policy Working Paper Series No. 20099. doi: $10.2139 /$ ssrn. 1418145 .

[18] Engle, F. R. and Granger, C.W. (1987). Co-Integration and Error Correction: Representation, Estimation, and Testing. Econometrica, Vol. 55, No. 2. (Mar., 1987), pp. 251-276. doi: $10.2307 / 1913236$.

[19] Erdem, C., Eroğlu, I., Demirel, B. (2017). The crowding out effect from the European debt crisis perspective: Eurozone experience, International Journal of Sustainable Economy9(1):1. doi: 10.1504/ijse.2017.10001608.

[20] Erenburg, S. (1993). The real effects of public investment on private investment, Applied Economics, vol. 25, no. 2, pp. 831-837. doi: 10.1080/00036849300000137.

[21] Huang, Y, Panizza, U. and Varghese, R. (2018). Does Public Debt Crowd Out Corporate Investment? International Evidence. The Graduate Institute Geneva May 2018. https://ssrn.com/abstract $=3178102$.

[22] Im, K. S., Pesaran, M. H. and Shin, Y. (2003): Testing for Unit Roots in Heterogeneous Panels. Journal of Econometrics, 115, 53-74. doi: 10.1016/s0304-4076(03)00092-7.

[23] Kao, C. (1999) Spurious regression and residual-based tests for cointegration in panel data, Journal of Econometrics, 90, pp.1-44. doi: 10.1016/s0304-4076(98)00023-2.

[24] Khan, R.E.A and Gill, A.R. (2009). Crowding Out Effect of Public Borrowing: A Case of Pakistan, University Library of Munich, München. https://ideas.repec.org/p/pra/mprapa/16292.html.

[25] Laubach,T. (2009). New evidence on the interest rate effects of budget deficits and debt Journal of the European Economic Association, MIT Press, vol. 7(4), pages 858-885, June. doi: 10.1162/jeea.2009.7.4.858.

[26] Levin, A., Lin, C. F. and Chu, C. J. (2002): Unit root tests in panel data: asymptotic and finite-sample properties. Journal of Econometrics, 108, 1-24. doi: 10.1016/s0304-4076(01)00098-7.

[27] Mankiw, G., Romer, D. and Weil, D. (1992). A Contribution to the Empirics of Economic Growth. The Quarterly Journal of Economics, Volume 107, Issue 2, May 1992, Pages 407-437, doi: $10.2307 / 2118477$.

[28] Mahmoudzadeh, Sadeghi and Sadeghi, S. (2013). Fiscal Spending and Crowding out Effect: A Comparison between Developed and Developing Countries. Institutions and Economies. Vol. 5, No. 1, pp. 31-40. http://ijie.um.edu.my/index.php/ijie/article/download/4873/2731.

[29] Mamatzakis, E. (2001). Public spending and private investment: Evidence from Greece, International economic journal, vol. 15, no 1. pp. 33-46. doi: 10.1080/10168730100080027.

[30] Modigliani, P. and Ando, A. (1976). Impacts of Fiscal Actions on Aggregate Income and the Monetarist Controversy: Theory and Evidence. Amsterdam: Monetarism. North-Holland. https://bit.ly/3go6hUx.

[31] Pedroni, P. (1996). Fully modified OLS for heterogeneous cointegrated panels and the case of purchasing power parity. Manuscript, Department of Economics, Indiana University 5:1-45. https://web.williams.edu/Economics/pedroni/WP-96-20.pdf

[32] Pedroni, P. (1999): Critical Values for Cointegration Tests in Heterogeneous Panels with Multiple Regressors. Oxford Bulletin of Economics and Statistics, 61, 653-670. doi: 10.1111/14680084.61.s1.14.

[33] Pesaran, M. H., and Smith, R.P. (1995). Estimating long-run relationships from dynamic heterogeneous panels. Journal of Econometrics 68: 79-113. doi: 10.1016/0304-4076(94)01644-F.

[34] Pesaran, M. H., Shin, Y. and Smith, R.P. (1997). Pooled Estimation of Long-run Relationships in Dynamic Heterogeneous Panels, Journal of the American Statistical Association, vol. 94, no. 446, 1999, pp. 621-634. doi: 10.2307/2670182.

[35] Pesaran, M.H., Shin, Y. and Smith, R.P. (1999). Pooled Mean Group Estimation of Dynamic Heterogeneous Panels. Journal of the American Statistical Association, 94(446), 621-634. doi: 10.1080/01621459.1999.10474156.

[36] Pesaran, M. H. (2007). A simple panel unit root test in the presence of cross section dependence. Journal of Applied Econometrics, 27, 265-312. doi: 10.1002/jae.951. 